\title{
Erratum to: Rhodococcus erythropolis as a host for expression, secretion and glycosylation of Mycobacterium tuberculosis proteins
}

Antonio J. Vallecillo ${ }^{1,2}$, Cristina Parada ${ }^{1}$, Pedro Morales ${ }^{1}$ and Clara Espitia ${ }^{1 *}$ (I)

\section{Erratum to: Microb Cell Fact (2017) 16:12 \\ DOI 10.1186/s12934-017-0628-6}

The authors of this published article [1] would like to add the following sentence to the 'Acknowledgements' section of the article [1]:

"We also thank the University program PASPA-UNAM for the scholarship granted to CE to carry out a sabbatical stay in Mucosal and Salivary Biology Division, King's College, Guy's Hospital, London, UK”.

\section{Author details}

${ }^{1}$ Departamento de Inmunología, Instituto de Investigaciones Biomédicas, Universidad Nacional Autónoma de México, C.P. 04510 Mexico, D.F., Mexico.

2 Present Address: Escuela de Medicina Veterinaria y Zootecnia, Facultad de Ciencias Agropecuarias, Universidad de Cuenca, C.P. 010220 Cuenca, Azu., Ecuador.

The online version of the original article can be found under doi:10.1186/s12934-017-0628-6.

\section{Publisher's Note}

Springer Nature remains neutral with regard to jurisdictional claims in published maps and institutional affiliations.

Received: 29 March 2017 Accepted: 29 March 2017

Published online: 19 April 2017

\section{Reference}

1. Vallecillo AJ, Parada C, Morales P, Espitia C. Rhodococcus erythropolis as a host for expression, secretion and glycosylation of Mycobacterium tuberculosis proteins. Microb Cell Fact. 2017;16:12. doi:10.1186/ s12934-017-0628-6.

*Correspondence: espitia@biomedicas.unam.mx

${ }^{1}$ Departamento de Inmunología, Instituto de Investigaciones Biomédicas,

Universidad Nacional Autónoma de México, C.P. 04510 Mexico, D.F.,

Mexico

Full list of author information is available at the end of the article 